\title{
Selection of Methods for Microbiological Extraction of Chitin from Shrimp Shells
}

\author{
JUNIANTO $^{1}$, BUDIASIH WAHYUNTARI $^{2} *$, AND SISWA SETYAHADI ${ }^{2}$

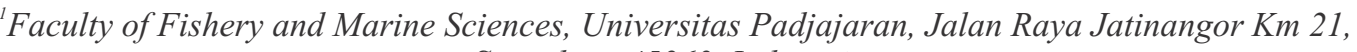 \\ Sumedang 45363, Indonesia; \\ ${ }^{2}$ Center for Bioindustrial Technology, Gedung 611, Laboratoria Pengembangan Teknologi Agro-Biomedika, Badan \\ Pengkajian dan Penerapan Teknologi, Kawasan Pusat Penelitian Ilmu Pengetahuan dan Teknologi, \\ Tangerang Selatan 15314, Indonesia
}

\begin{abstract}
Chitin extraction from shrimp shells involves two processing steps that are demineralization followed by deproteination process. Lactobacillus acidophilus FNCC 116 and Bacillus licheniformis F11.1 were used in demineralization and deproteination respectively. The overall objectives of this experiment were to determine fermentation systems which resulted in the highest mineral and protein removal. The demineralization experiments consisted of three different batch fermentation designs: batch fermentation $\left(\mathrm{A}_{\mathrm{m}}\right)$; subsequent batch fermentation 1 , in which $100 \%$ medium was replaced with fresh medium after $24 \mathrm{~h}$ fermentation $\left(\mathrm{B}_{\mathrm{m}}\right)$; and subsequent batch fermentation 2, in which $50 \%$ medium was replaced with the same amount of fresh medium after $24 \mathrm{~h}$ fermentation $\left(\mathrm{C}_{\mathrm{m}}\right)$. The demineralization was conducted at $30 \pm 2{ }^{\circ} \mathrm{C}, 50 \mathrm{rpm}$ for $60 \mathrm{~h}$. The deproteination experiments consisted of 3 different batch fermentation designs: batch fermentation 1, inoculum was added once at the beginning of the fermentation $\left(\mathrm{A}_{\mathrm{p}}\right.$ ); batch fermentation 2, inoculum was added twice, at the beginning and after $24 \mathrm{~h}$ fermentation $\left(\mathrm{B}_{\mathrm{p}}\right)$; and subsequent batch fermentation, $100 \%$ medium was replaced with fresh medium after $24 \mathrm{~h}$ fermentation $\left(\mathrm{C}_{\mathrm{p}}\right)$. The deproteination was carried out at $55^{\circ} \mathrm{C}, \mathrm{pH} 7.8-8.0$, aeration $2.3 \mathrm{vvm}$ and agitation $275 \mathrm{rpm}$ for $96 \mathrm{~h}$. The experimental results showed that in the demineralization process, fermentation design $B_{m}$ gave the highest ash removal. Ash removed in the fermentation design $A_{m}, B_{m}$, and $C_{m}$ was $97.19,99.69$, and $97.69 \%$ respectively. The protein removed in the fermentation design $A_{p}, B_{p}$, and $C_{p}$ was $94.42,94.51$, and $95.37 \%$ respectively.
\end{abstract}

Key words: demineralization, deproteination, microbiological chitin extraction, shrimp shells

Ekstraksi kitin dari kulit udang terdiri atas dua tahap proses yaitu proses demineralisasi dilanjutkan dengan deproteinasi. Lactobacillus acidophilus FNCC 116 dan Bacillus licheniformis F11.1 masing-masing digunakan untuk proses demineralisasi dan deproteinasi. Tujuan penelitian ini adalah untuk menentukan sistem fermentasi yang dapat menghilangkan mineral dan protein dari kulit udang terbanyak. Percobaan demineralisasi terdiri atas 3 rancangan fermentasi sistem tumpak yang berbeda: fermentasi sistem tumpak $\left(\mathrm{A}_{\mathrm{m}}\right)$; fermentasi sistem tumpak berurutan 1, di mana 100\% medium diganti dengan medium segar sesudah fermentasi 24 jam $\left(\mathrm{B}_{\mathrm{m}}\right)$; dan fermentasi sistem tumpak berurutan 2, di mana $50 \%$ medium diganti dengan medium segar dalam jumlah yang sama sesudah fermentasi $24 \mathrm{jam}\left(\mathrm{C}_{\mathrm{m}}\right)$. Proses demineralisasi dilakukan pada $30 \pm 2^{\circ} \mathrm{C}, 50 \mathrm{rpm}$ selama $60 \mathrm{jam}$. Percobaan deproteinasi terdiri atas 3 rancangan proses yang berbeda: fermentasi sistem tumpak $\left(\mathrm{A}_{\mathrm{p}}\right)$, inokulum ditambahkan sekali pada awal fermentasi; fermentasi sistem tumpak $2\left(\mathrm{~B}_{\mathrm{p}}\right)$, inokulum ditambahkan 2 kali, pada awal dan setelah fermentasi $24 \mathrm{jam}$; fermentasi sistem tumpak berurutan: $100 \%$ medium diganti dengan medium segar setelah $24 \mathrm{jam}\left(\mathrm{C}_{\mathrm{p}}\right)$. Proses deproteinasi dilakukan pada $55^{\circ} \mathrm{C}$, $\mathrm{pH} 7,8-8,0$, aerasi 2,3 vvm dan agitasi 275 $\mathrm{rpm}$ selama $96 \mathrm{jam}$. Hasil percobaan menunjukkan bahwa dalam proses demineralisasi, rancangan fermentasi $\mathrm{B}_{\mathrm{m}}$ dapat menghilangkan kadar abu terbanyak. Kadar abu yang dihilangkan dalam rancangan fermentasi $\mathrm{A}_{\mathrm{m}}, \mathrm{B}_{\mathrm{m}}$, dan $\mathrm{C}_{\mathrm{m}}$ masing-masing $97,19 \%, 99,69 \%$, dan $97,69 \%$. Pada proses deproteinasi, protein yang dihilangkan dari rancangan fermentasi $\mathrm{A}_{\mathrm{p}}, \mathrm{B}_{\mathrm{p}}$, dan $\mathrm{C}_{\mathrm{p}}$ masing-masing $94,42 \%, 94,51 \%$, dan $95,37 \%$.

Kata kunci: demineralisasi, deproteinasi, ekstraksi kitin secara mikrobiologi, kulit udang

Chitin is a homopolymer of $\mathrm{N}$-acetyl-D-glucosamine residues linked by $\beta-1,4$ bonds. Chitin and its derivatives have many applications in food, pharmaceutical, photography, cosmetic, paper, and textile industries (Dutta et al. 2004). Chitin can be found in various animals and plants and the crustacean is the most important chitin source for commercial use. In

*Corresponding author; Phone: +62-21-7560536, Fax: +6221-7566922,E-mail: solichin.budiasih@gmail.com crustacean waste chitin is associated with protein, minerals, especially calcium carbonate, lipids, and pigments (Mahmoud et al. 2007). Consequently, to extract chitin from crustacean waste will involve removal of the protein (deproteination), minerals (demineralization), lipids, and pigments. Conventional chitin extraction used harsh chemicals that caused environmental pollution, since concentrated hydrochloric acid was used for demineralization and sodium 
hydroxide for deproteination. Some studies have been done to reduce or even to eliminate the environmental problems (Healy et al. 2003; Beaney et al. 2005; Rao and Stevens 2005; Jung et al.2006; and Prameela et al.2010). These studies include deproteination of the crustacean shells using proteolytic enzyme or microorganisms. Beaney et al. (2005) showed that the functional properties of the bioprocessed chitin were similar to those of chemically extracted chitin. Microbiological demineralization and deproteination have been done by Healy et al. (2003), Rao and Stevens (2005), Jung et al. (2006), and Prameela et al. (2010).

Based on our previous study, demineralization prior to deproteination in chitin extraction resulted in better ash and protein removal (Wahyuntari et al. 2011). The objective of trying different demineralization experiments was to find the optimum lactic acid production in order to get maximum ash removal. Parameters observed in this experiment were growth of Lactobacillus acidophilus FNCC 116, glucose consumed by the bacteria during fermentation, lactic acid produced, and $\mathrm{pH}$ course during fermentation. Three different deproteination experiments were done to optimize protease production for hydrolyzing protein in the shrimp shells. The parameters studied were bacterial growth of Bacillus licheniformis F11.1, protease produced and protein content of the protease supernatant (cell free fermented broth).

\section{MATERIAL AND METHODS}

Shrimp Shells and Microorganisms. Headless shrimp shells of Penaeus vannamei were obtained from frozen shrimp processing company "PT Wirontono Baru" North Jakarta, Indonesia. The shells were washed and disintegrated into 5-10 mm size, kept in $-20^{\circ} \mathrm{C}$ before using it for experiments.

L. acidophilus FNCC 116, a lactic acid producing bacterium was used for demineralization process. The bacterium was obtained from Food Nutrition Culture Collection of Faculty of Agicultural Technology, Universitas Gadjah Mada, Yogyakarta, Indonesia. The stock cultures in $10 \%$ glycerol and $10 \%$ skimmed milk were stored in deep freezer at $-80{ }^{\circ} \mathrm{C}$.

B. licheniformis F.11-1 used for deproteination process of shrimp shells was isolated from shrimp shell waste of PT Lauraindo, a frozen shrimp processing company, Palembang, Sumatera, Indonesia. The bacterium was isolated and identified by Waldeck et al (2006) and molecularly modified by Hoffman et al (2010). The stock culture was kept in $10 \%$ glycerol and
$10 \%$ skimmed milk at $-80{ }^{\circ} \mathrm{C}$.

Demineralization Process. Completely randomized design was used in experiment of shrimp shell demineralization. The demineralization experiments consisted of 3 different batch fermentation designs: batch fermentation $\left(\mathrm{A}_{\mathrm{m}}\right)$; subsequent batch fermentation $1\left(\mathrm{~B}_{\mathrm{m}}\right), 100 \%$ medium was replaced with fresh medium after $24 \mathrm{~h}$ fermentation (the fermented medium was centrifuged to separate the cells and shrimp shells waste, the supernatant was discarded and replaced with fresh medium); subsequent batch fermentation 2 $\left(\mathrm{C}_{\mathrm{m}}\right)$, in which $50 \%$ medium was replaced with the same amount of fresh medium after $24 \mathrm{~h}$ fermentation. The demineralization was conducted in $2 \mathrm{~L}$ fermentor (contained $1 \mathrm{~L}$ medium) at $30 \pm 2{ }^{\circ} \mathrm{C}, 50 \mathrm{rpm}$ for $60 \mathrm{~h}$. Refreshing frozen stock culture was conducted by transferring $1 \mathrm{~mL}$ stock culture into $9 \mathrm{~mL}$ of sterile de Man Rogosa Sharpe (MRS) broth and incubated at 37 ${ }^{\circ} \mathrm{C}$ for $24 \mathrm{~h}$. To prepare a starter inoculum, $10 \mathrm{~mL}$ refreshed culture was transferred into $90 \mathrm{~mL}$ MRS broth in $250 \mathrm{~mL}$ Erlenmeyer flask and incubated at 37 ${ }^{\circ} \mathrm{C}$ until its optical density reached 0.85 at wavelength of $600 \mathrm{~nm}$ with cell concentration about $1 \times 10^{9} \mathrm{CFU}$ $\mathrm{mL}^{-1}$. Based on previous study optimum demineralization condition was at ambient temperature $\left(30 \pm 2{ }^{\circ} \mathrm{C}\right)$ and $50 \mathrm{rpm}$ agitation (Junianto et al. 2009). Three hundred grams frozen shrimp shell waste $(69.5 \%$ moisture) were added with $900 \mathrm{~mL}$ liquid media and $100 \mathrm{~mL}$ starter inoculums. In $100 \mathrm{~mL}$ medium contained $6 \mathrm{~g}$ glucose, and $0.05 \mathrm{~g}$ yeast extract, $\mathrm{pH}$ was adjusted to $\mathrm{pH} 7$. The fermentation was done at $37^{\circ} \mathrm{C}$ and $50 \mathrm{rpm}$ agitation for $48 \mathrm{~h}$. Each experiment was repeated twice. When demineralization process was completed, the shells were separated from the broth and washed with running water until the washed water became neutral $(\mathrm{pH} 7)$ and drained. The demineralized shells then were kept in $-20{ }^{\circ} \mathrm{C}$ for the following process.

Deproteination Process. Completely randomized design was used in the deproteination experiment of demineralized shrimp shells. The deproteination experiments consisted of 3 different batch fermentation designs: batch fermentation $1\left(\mathrm{~A}_{\mathrm{p}}\right)$, inoculumn was added once at the beginning of the fermentation; batch fermentation $2\left(B_{p}\right)$, inoculum was added twice, at the the beginning and after $24 \mathrm{~h}$ fermentation; subsequent batch fermentation $\left(\mathrm{C}_{\mathrm{p}}\right), 100 \%$ medium was replaced with fresh medium after $24 \mathrm{~h}$ fermentation (the fermented medium was centrifuged to separate the cells and shrimp shells waste, the supernatant was discarded and replaced with fresh medium). The frozen stock 
culture of B. licheniformis F11.1 was refreshed in Luria broth media. The culture was incubated in shaker incubator at $55{ }^{\circ} \mathrm{C}, 180 \mathrm{rpm}$ for $6 \mathrm{~h}$ or until the optical density of the culture reached 0.9 , which based on previous experiment the cell density was equal to $1 \times 10^{9}$ CFU $\mathrm{mL}^{-1}$ (Junianto et al. 2009). Each $100 \mathrm{~mL}$ fermentation medium contained $0.5 \mathrm{~g} \mathrm{KH}_{2} \mathrm{PO}_{4}, 0.5 \mathrm{~g}$ $\mathrm{NaCl}, 0.5$ g yeast extract, $0.05 \mathrm{~g} \mathrm{MgSO}_{4}$, and $0.1 \mathrm{~g}$ $\mathrm{CaCl}_{2}$. Two hundreds $\mathrm{mL}$ inoculum was added into 300 $\mathrm{g}$ of shrimp shells in $800 \mathrm{~mL}$ medium. The fermentation was carried out at $55{ }^{\circ} \mathrm{C}, 2.5 \mathrm{vvm}$ aeration, $275 \mathrm{rpm}$ agitation for $60 \mathrm{~h}$ and the $\mathrm{pH}$ was maintained at the range of 7.8-8.2. Samples for analytical assays were taken every $6 \mathrm{~h}$. After the deproteination process completed, the shells were separated from the broth, washed, drained, and kept at $20^{\circ} \mathrm{C}$ for the following process.

All fermentations were conducted in custom made fermentor consisted of $2 \mathrm{~L}$ glass cylinder jar equipped with Jake and Kunkel rod agitator for agitation, a compressor connected to LKB-Bromma, flow meter for aeration and heated water in water bath that was being circulated using coil into the jar for temperature control. The shrimp shells were not sterilized prior to any fermentation.

Analytical Procedures. Demineralization process of the shrimp shells (before, during, and after fermentation), moisture, ash, and insoluble protein content of the shrimp shells were observed, whereas the parameters observed of the fermented broth in demineralization process were bacterial density, glucose, lactic acid, and pH. Parameters observed during deproteination process were bacterial density and protease production in the fermented broth, as well as protein content of the shrimp shells. Moisture content was determined by heating samples at $110{ }^{\circ} \mathrm{C}$ in "Kett" infrared moisterure meter model F-1A (Tokyo, Japan). Ash content was determined after combustion of $5 \mathrm{~g}$ dried sample in a crucible at $600{ }^{\circ} \mathrm{C}$ for $4 \mathrm{~h}$ in muffle furnace (AOAC 1984). Insoluble protein content of the shrimp shells and fermented solid sample was solubilized using $1 \mathrm{M} \mathrm{NaOH}$. Seven poin five (7.5) $\mathrm{mL}$ of $1 \mathrm{M} \mathrm{NaOH}$ was added to $0.5 \mathrm{~g}$ sample and then incubated for $24 \mathrm{~h}$. The protein content of the supernatant was measured according to Lowry et al. (1951) method using bovine serum albumin fraction IV (Sigma) as a standard.

Glucose and lactic acid content was analyzed using HPLC (Merck-Hitachi), Aminex column HPX-87H $(300 \mathrm{~mm} \times 7.8 \mathrm{~mm})$, at $65^{\circ} \mathrm{C}(\mathrm{L}-5025$-Column Thermostat), isocratic mobile phase of $0,005 \mathrm{~N} \mathrm{H}_{2} \mathrm{SO}_{4}$ with flow rate of $0.6 \mathrm{~mL} \mathrm{~min}{ }^{-1}$ (L-6200A-Pump, Merck-
Hitachi), differential refractometer detector RI-71 (Merck). Glucose standard used 1\% glucose (SigmaAldrich) and lactic acid standard was 10\% L-lactic acid (Oxoid).

Protease activity in fermented broth was assayed using azocasein as a substrate according to the method described by Waldeck et al. (2006). One unit was defined as the amount of enzyme releasing $1 \mathrm{~mol}$ azocasein per min under reaction conditions. The density of bacterial growth in fermentation broth was assayed after serial dilution by counting colony forming unit $\left(\mathrm{CFU} \mathrm{mL}^{-1}\right)$ on MRS agar plate after incubation at $37^{\circ} \mathrm{C}, 24 \mathrm{~h}$ for L. acidophilus FNCC116 and on Luria Bertani agar plate after incubation at 55 ${ }^{\circ} \mathrm{C}, 24 \mathrm{~h}$ for $B$. licheniformis $\mathrm{F} 11.1$.

Decrease of the ash and protein content in shrimp shells were analyzed statistically using $\mathrm{F}$ test and Duncan's multiple range tests at $95 \%$ confidence. Experimental results of other parameters were descriptively analyzed in the graphic forms.

Chitin concentration of the demineralized and deproteinized shrimp shells was calculated based on equation 1, according to Mizani and Aminlari (2007).

$$
\text { Chitin }(\%)=\text { chitin nitrogen } \times 14.25
$$

Total nitrogen of the demineralized and deproteinized shrimp shells (chitin) was analysed using Kjeldhal method (AOAC 1984).

\section{RESULTS}

Demineralization. Bacterial growth in batch fermentation $\mathrm{A}_{\mathrm{m}}$ reached the maximum growth (1.96 $\times$ $10^{9} \mathrm{CFU} \mathrm{mL}^{-1}$ ) after $24 \mathrm{~h}$ fermentation, and then started decreasing afterward until the end of observation $(2.53 \times$ $10^{8} \mathrm{CFU}$ after $60 \mathrm{~h}$ ) (Fig 1). Maximum bacterial growth in fermentation $\mathrm{B}_{\mathrm{m}}$ was also reached after $24 \mathrm{~h}(1.81 \times$ $\left.10^{9} \mathrm{CFU}\right)$. Eighteen $\mathrm{h}$ after replacing the medium or $42 \mathrm{~h}$ from the beginning of fermentation, the cell amount reached $2.07 \times 10^{9} \mathrm{CFU}$, and then the cell amount decreased to $5.78 \times 10^{8} \mathrm{CFU}$ at the end of fermentation (60 h observation) (Fig 1). In the second subsequent batch $\mathrm{C}_{\mathrm{m}}$, the maximum cell growth reached $1.99 \times 10^{9}$ $\mathrm{CFU}$ after $24 \mathrm{~h}$. After replacing 50\% medium with the fresh one, the cells reached maximum amount of $1.55 \times$ $10^{9} \mathrm{CFU}$ after $12 \mathrm{~h}$ or after $36 \mathrm{~h}$ since the beginning of fermentation, then the cell amount decreased to $5.68 \times$ $10^{8} \mathrm{CFU}$ at the end of observation (Fig 1).

Initial glucose concentration was $6 \%(\mathrm{w} / \mathrm{v})$, and after $24 \mathrm{~h}$ fermentation the remaining concentration of the 
glucose of all fermentation design was about $1 \%(\mathrm{w} / \mathrm{v})$ (Fig 2). In fermentation $\mathrm{B}_{\mathrm{m}}$ and $\mathrm{C}_{\mathrm{m}}$, the medium was replaced after $24 \mathrm{~h}$ with a $100 \%$ and $50 \%$ fresh medium, thus there was glucose addition. The rapid decrease of glucose concentration in the first 6 to $24 \mathrm{~h}$ afterward (Fig 2) corresponded to the increase of bacterial cells (Fig 1). After $48 \mathrm{~h}$ fermentation, glucose in the medium was continuously consumed until the end of the observation, where less than $2 \%$ glucose remained.

Lactic acid produced in all fermentation designs after the first $24 \mathrm{~h}$ of fermentation was about the same which was $2.17,2.30$, and $2.26 \%$, repectively. After that, lactic acid concentration in batch fermentation $\mathrm{A}_{\mathrm{m}}$ did not increase. However, the lactic acid concentration in fermentation $B_{m}$ and $C_{m}$ increased after fresh medium addition. The highest lactic concentration was produced in $\mathrm{B}_{\mathrm{m}}(4.19 \%)$ and in $\mathrm{C}_{\mathrm{m}}(3.42 \%)$ (Fig 3).

The $\mathrm{pH}$ value of the fermentation broth depended on the lactic acid concentration. The lowest $\mathrm{pH}$ was achieved in fermentation $\mathrm{B}_{\mathrm{m}}(\mathrm{pH}$ 3.88) and the highest $\mathrm{pH}_{\text {in }} \mathrm{A}_{\mathrm{m}}$ (pH 4.61)(Fig 4). The ash concentration in the shell in all treatments decreased rapidly for the first 24 $\mathrm{h}$, and then the ash removal was slowing down until the end of observation. The ash concentration of the shells in $\mathrm{A}_{\mathrm{m}}, \mathrm{B}_{\mathrm{m}}$, and $\mathrm{C}_{\mathrm{m}}$ was $0.55,0.06$, and $0.45 \%$ which represented $97.19,99.69$, and $97.69 \%$ ash removed respectively (Fig 5).

Deproteination. Maximum bacterial growth of all fermentation systems was reached after $12 \mathrm{~h}$ incubation, and then started declining for the following $12 \mathrm{~h}$, in fermentation $\mathrm{A}_{\mathrm{p}}$ continuously declining until the end of observation. After addition of inoculum in fermentation $\mathrm{B}_{\mathrm{p}}$ and replacement of medium in $\mathrm{C}_{\mathrm{p}}$, the cell amount started increasing. The cell amount in $\mathrm{B}_{\mathrm{p}}$ started declining $6 \mathrm{~h}$ after addition of inoculum and in $\mathrm{C}_{\mathrm{p}}$ declined gadually for the following $12 \mathrm{~h}$ and decreased fast for the last $6 \mathrm{~h}$ of observation (Fig 6).

Maximum production of protease during deproteination in $A_{p}, B_{p}$ and $C_{p}$ was reached after 48,72 , and $72 \mathrm{~h}$ incubation respectively. The highest enzyme activity was $16.51 \mathrm{U} \mathrm{mL}^{-1}$ in $\mathrm{B}_{\mathrm{p}}$, the second was $16.06 \mathrm{U}$ $\mathrm{mL}^{-1}$ in $\mathrm{A}_{\mathrm{p}}$, and the lowest was $11.63 \mathrm{U} \mathrm{mL}^{-1}$ in $\mathrm{C}_{\mathrm{p}}$ (Fig 7). Protein concentration of the shrimp shells in fermentation system $A_{m}, B_{m}$, and $C_{m} 5.58,5.49$, and $4.63 \%$ respectively which represented 94.42, 94.51, and $95.37 \%$ protein removed. Aproximate analysis of chitin produced by combination of demineralization $B_{m}$ and deproteination $\mathrm{A}_{\mathrm{p}}$ showed as follows: $0.84 \%$ ash, $1.46 \%$ protein, and $97.85 \%$ chitin (\% dry base).

\section{DISCUSION}

Based on our previous report, in the microbiological chitin extraction from shrimp shells, demineralization prior to deproteination gave a better chitin yield (Wahyuntari et al. 2011), therefore in this experiment, demineralization was carried out before deproteination process.

Demineralization. Fermentation system of $L$. acidophilus FNCC 116 used for lactic acid production in this experiment was batch and modification of fed batch. Batch, fed batch, or modification of both systems are common fermentation system used in industries (Hsu and Wu 2002). The efficiency of lactic

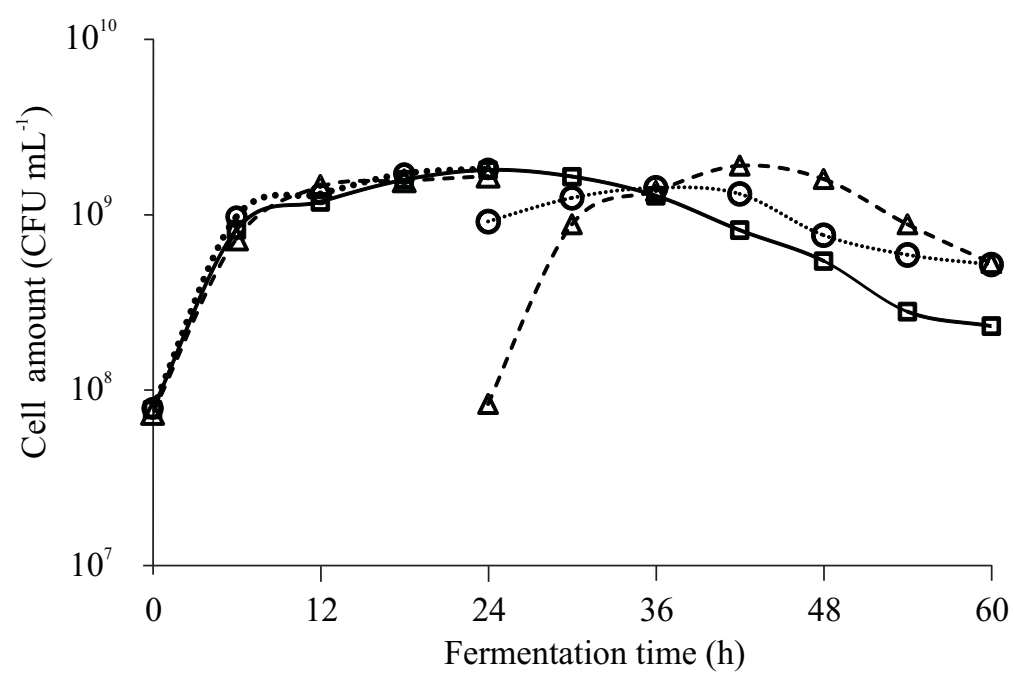

Fig 1 Growth of Lactobacillus acidophilus FNCC 116 in different fermentation systems. $A_{m}(\square)$ : batch fermentation; $B_{m}(\triangle)$ : subsequent batch fermentation, in which $100 \%$ medium was replaced with fresh medium after $24 \mathrm{~h}$ fermentation; $\mathrm{C}_{\mathrm{m}}(\mathrm{O})$ : subsequent batch fermentation, in which $50 \%$ medium was replaced with the same amount of fresh medium after $24 \mathrm{~h}$ fermentation. 


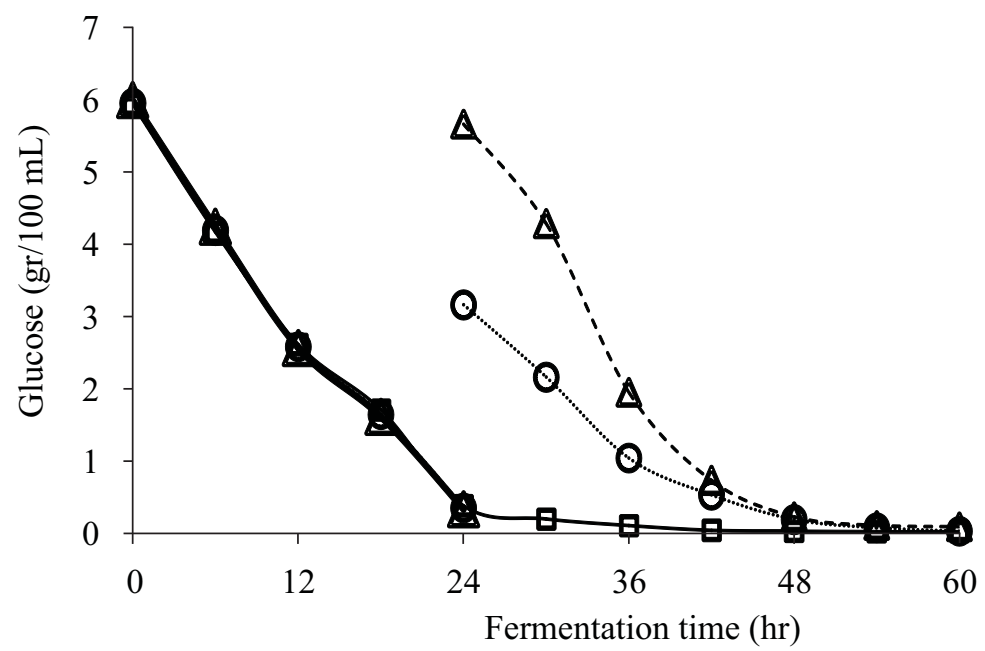

Fig 2 Glucose consumption during demineralization of shrimp shells by Lactobacillus acidophilus FNCC 116 in different fermentation systems. $A_{m}(\square)$ : Batch fermentation; $B_{m}(\triangle)$ : Subsequent batch fermentation, $100 \%$ medium was replaced with fresh medium after $24 \mathrm{~h}$ fermentation; $\mathrm{C}_{\mathrm{m}}(\mathrm{O})$ : Subsequent batch fermentation, $50 \%$ medium was replaced with the same amount of fresh medium after $24 \mathrm{~h}$ fermentation.

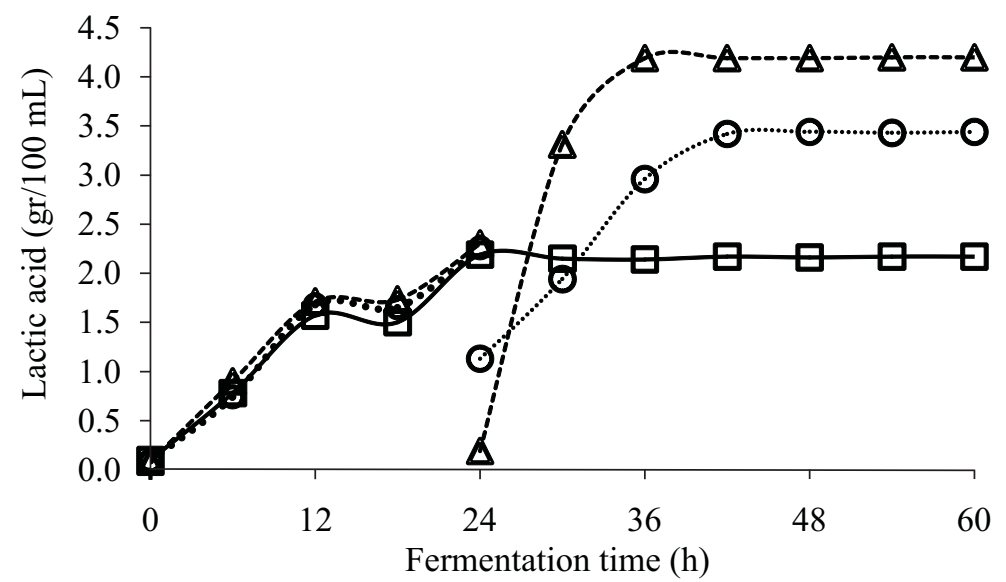

Fig 3 Lactic acid production during demineralization of shrimp shells by Lactobacillus acidophilus FNCC 116 in different fermentation systems. $A_{m}(\square)$ : Batch fermentation; $B_{m}(\triangle)$ : Subsequent batch fermentation, $100 \%$ medium was replaced with fresh medium after $24 \mathrm{~h}$ fermentation; $\mathrm{C}_{\mathrm{m}}(\mathrm{O})$ : Subsequent batch fermentation, $50 \%$ medium was replaced with the same amount of fresh medium after $24 \mathrm{~h}$ fermentation.

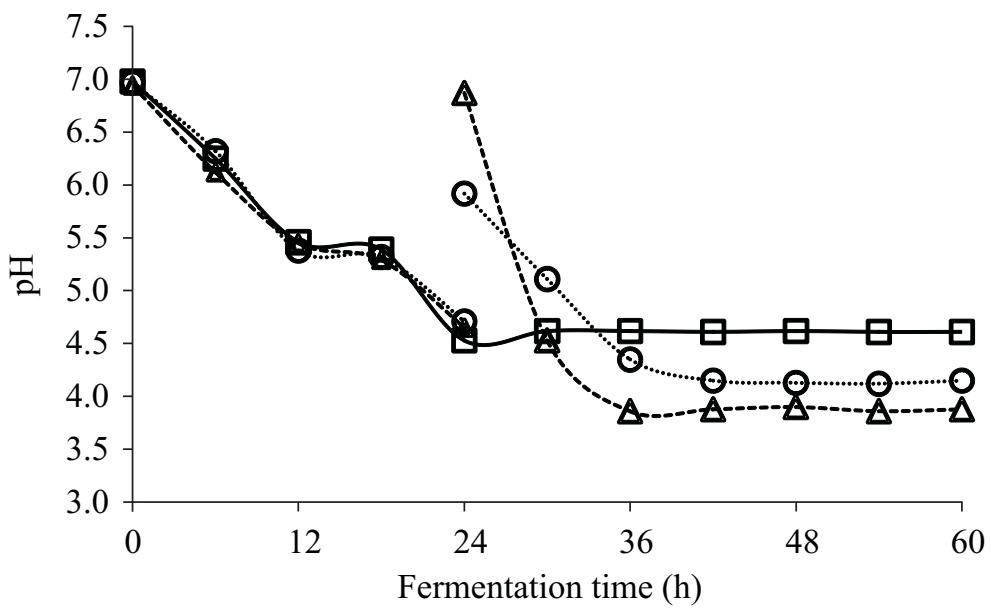

Fig $4 \mathrm{pH}$ of fermented broth during demineralization of shrimp shells by Lactobacillus acidophilus FNCC 116 in different fermentation systems. $A_{m}(\square)$ : Batch fermentation; $B_{m}(\triangle)$ : Subsequent batch fermentation, $100 \%$ medium was replaced with fresh medium after $24 \mathrm{~h}$ fermentation; $\mathrm{C}_{\mathrm{m}}(\mathrm{O})$ : Subsequent batch fermentation, $50 \%$ medium was replaced with the same amount of fresh medium after $24 \mathrm{~h}$ fermentation. 


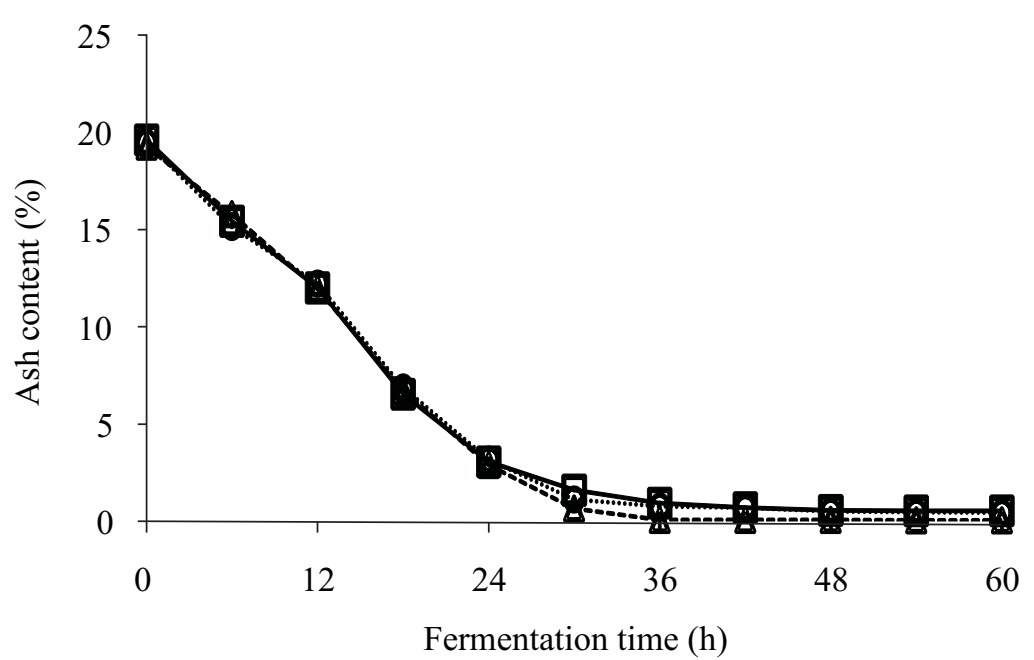

Fig 5 Ash content in shrimp shells during demineralization of shrimp shells by Lactobacillus acidophilus FNCC 116 in different fermentation systems. $A_{m}(\square)$ : batch fermentation; $B_{m}(\triangle)$ : subsequent batch fermentation, $100 \%$ medium was replaced with fresh medium after $24 \mathrm{~h}$ fermentation; $\mathrm{C}_{\mathrm{m}}(\mathrm{O})$ : subsequent batch fermentation, $50 \%$ medium was replaced with the same amount of fresh medium after $24 \mathrm{~h}$ fermentation.

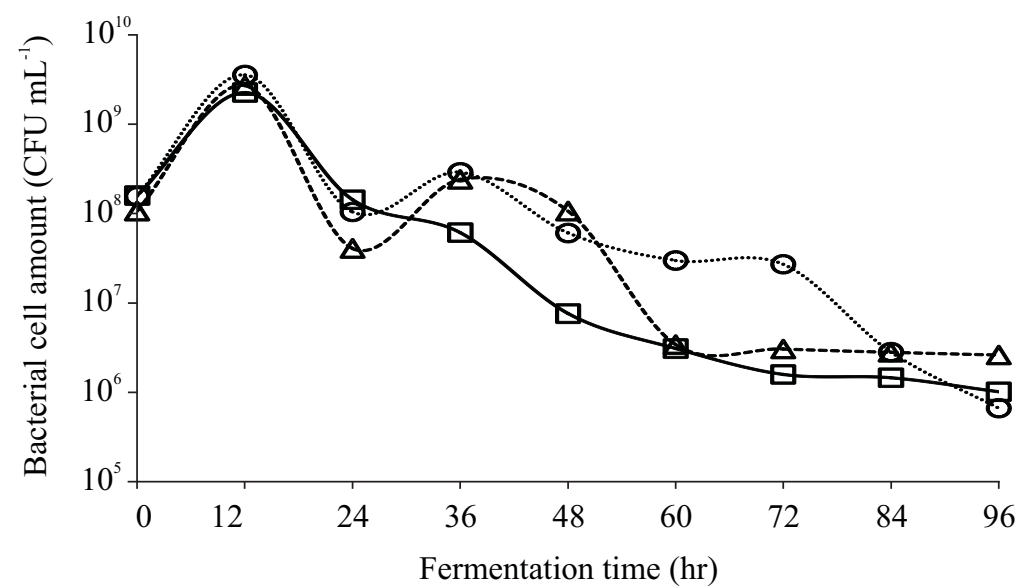

Fig 6 Growth of Bacillus licheniformis F.11.1 during deproteination of shrimp shells. $A_{p}(\square)$ : batch fermentation 1, inoculum was added once at the beginning of the fermentaion; $B_{p}(\triangle)$ : batch fermentation 2, inoculum was added twice, at the beginning and after $24 \mathrm{~h}$ fermentation; $\mathrm{C}_{\mathrm{p}}(\mathrm{O})$ : subsequent batch fermentation, $100 \%$ medium was replaced with fresh medium after $24 \mathrm{~h}$ fermentation.

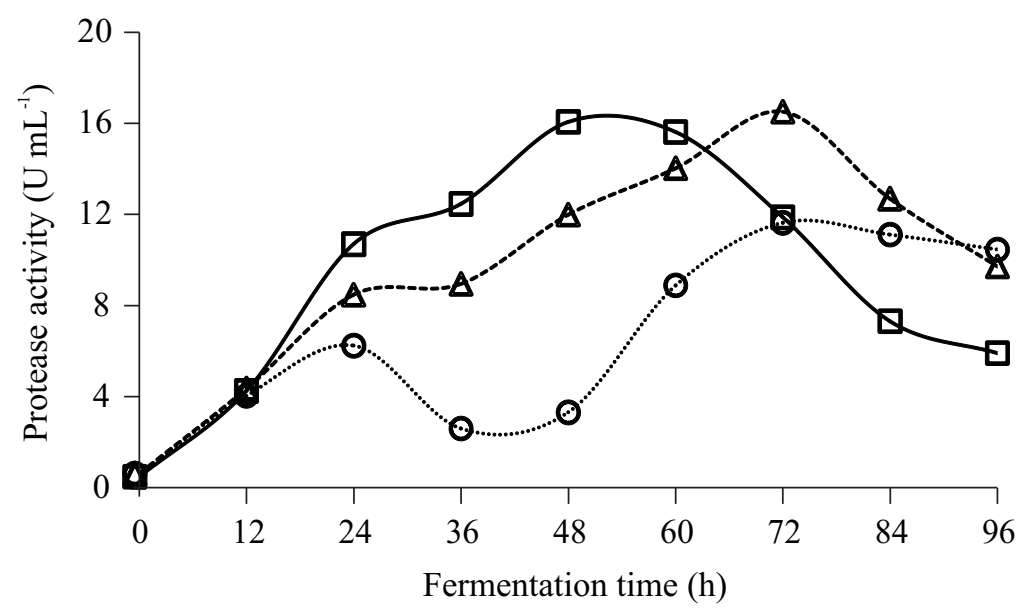

Fig 7 Protease production during deproteination of shrimp shells using Bacillus licheniformis F11.1. $\mathrm{A}_{\mathrm{p}}(\square)$ : batch fermentation 1 , inoculum was added once at the beginning of the fermentation; $B_{p}(\triangle)$ : batch fermentation 2, inoculum was added twice, at the beginning and after $24 \mathrm{~h}$ fermentation; $\mathrm{C}_{\mathrm{p}}(\mathrm{O})$ : subsequent batch fermentation, $100 \%$ medium was replaced with fresh medium after $24 \mathrm{~h}$ fermentation. 


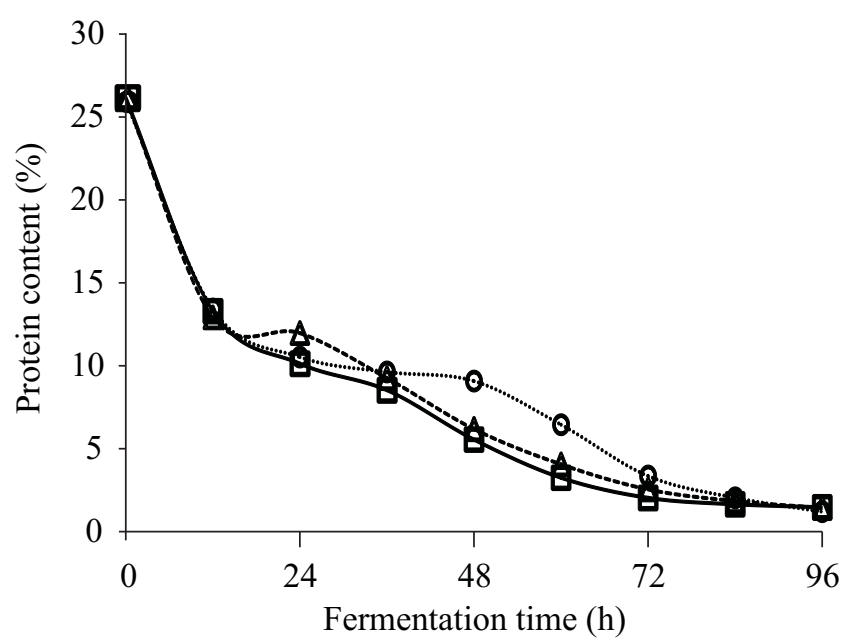

Fig 8 Protein content of shrimp shells during deproteination using Bacillus licheniformis F11.1. $A_{p}(\square)$ : batch fermentation 1, inoculumn was added once at the beginning of the fermentaion; $\mathrm{B}_{\mathrm{p}}(\triangle)$ : batch fermentation 2 , inoculumn was added twice, at the beginning and after $24 \mathrm{~h}$ fermentation; $\mathrm{C}_{\mathrm{p}}(\mathrm{O})$ : subsequent batch fermentation, $100 \%$ medium was replaced with fresh medium after $24 \mathrm{~h}$ fermentation.

acid fermentation depends on some factors such as inoculum density, glucose concentration, and initial $\mathrm{pH}$, during fermentation as well as fermentation time (Rao et al. 2000). L. acidophilus is a homofermentative lactic acid bacterium which produces lactic acid as a major product from glucose (Jafarei and Ebrahimi 2011). Based on experimental data, the bacterial exponential growth was associated with the glucose consumed and the lactic acid produced. In this demineralization experiment, initial $\mathrm{pH}$ and glucose concentration in the medium used in all batch process was $\mathrm{pH} 7$ and 6\%, respectively, with cell density of bacterial starter $8.5 \times 10^{8} \mathrm{CFU} \mathrm{mL}{ }^{-1}$. The effect of glucose concentration in the medium on lactic acid production was observed by applying three different fermentation schemes (fermentation $\mathrm{A}_{\mathrm{m}}, \mathrm{B}_{\mathrm{m}}$, and $\mathrm{C}_{\mathrm{m}}$ ). The aim of applying three different fermentations of lactic acid bacteria was to find the optimum lactic acid production. Since the lactic acid produced would react with calcium carbonate in chitin fraction of the shrimp shells to form calcium lactate which precipitate and can be removed by washing (Rao and Stevens 2005). Therefore, the more lactic acid produced, as expected the more calcium carbonate in the shrimp shells could be removed. Our proximate analysis showed that Calcium content of our sample was $39.21 \%$ of the ash content. The calcium removed was observed by analyzing the ash content of the shells, thus the more calcium removed the less ash content of the shells.

Experimental data showed that exponential growth phase of L. acidophilus FNCC116 lasted for $6 \mathrm{~h}$ for all batch system $\left(A_{m}, B_{m}\right.$, and $\left.C_{m}\right)($ Fig 1). After the first $6 \mathrm{~h}$ of fermentation, the bacteria grew exponentialy in batch $A_{m}$ followed by stationary phase until $36 \mathrm{~h}$ incubation. When $100 \%$ medium was replaced with the fresh one in $\mathrm{B}_{\mathrm{m}}$, the cell undergone exponential phase again from $24 \mathrm{~h}$ to $36 \mathrm{~h}$ incubation. However, the maximum cell amount between $A_{m}$ and $B_{m}$ was not much different. When the medium was only replaced $50 \%\left(\mathrm{C}_{\mathrm{m}}\right)$, the cells did not grow as much as in $\mathrm{B}_{\mathrm{m}}$. In the exponential phase, the cells consumed most of the nutrients in the medium and in this experiment, the change of glucose concentration in the medium was observed. In the first $24 \mathrm{~h}$, glucose concentration declined very rapidly in all fermentation system from $6 \%(\mathrm{w} / \mathrm{v})$ and down to $<1 \%(\mathrm{w} / \mathrm{v})$. After replacement of the medium, the glucose concentration returned to the original concentration in $\mathrm{B}_{\mathrm{m}}$ since the medium was $100 \%$ replaced with the fresh one, whereas in $\mathrm{C}_{\mathrm{m}}$ the medium was only replaced $50 \%$, the glucose concentration became 3.16\% (w/v) (Fig 2). After $48 \mathrm{~h}$ of incubation until the end of observation $(60 \mathrm{~h})$ the glucose concentration barely changed $(<0.2 \%)$.

Glucose consumed by the bacteria (Fig 2) was associated with lactic acid production (Fig 3). Lactic acid concentration increased rapidly up to $2.19-2.3 \%$ in the first $24 \mathrm{~h}$ in all fermentation systems which were related with the decrease of glucose concentration (Fig 2 ) and $\mathrm{pH}$ (Fig 4) in the medium. The data show that $L$. acidhophilus FNCC 116 converted some of glucose to lactic acid. Maximum concentration of lactic acid reached in $\mathrm{A}_{\mathrm{m}}$ was $2.19 \%(\mathrm{w} / \mathrm{v})$ and it did not change until the end of observation $(60 \mathrm{~h})$. Among the three fermentation systems, the highest lactic acid was in the system with $100 \%$ medium replacement $\left(\mathrm{B}_{\mathrm{m}}\right)$. The highest lactic acid concentration was $4.19 \%$ (w/v) $12 \mathrm{~h}$ 
after the medium replacement and the concentration remained at that value $(4.2 \% \mathrm{w} / \mathrm{v})$ until the end of observation (60 h) (Fig 3). In fermentation system $\mathrm{C}_{\mathrm{m}}$, where only $50 \%$ of the medium was replaced, the maximum lactic acid concentration was only $3.44 \%$ (w/v) (Fig 3). These data indicate that glucose added into the medium was mostly converted to lactic acid. Prameela et al (2010) study on chitin extraction using L. plantarum (ATCC 8014 and NRRL B-14768), L. pentosus (ATCC 8041), and L. fermentum (NRRL B 1840) showed that the more glucose added the more lactic acid produced. The lactic acid produced affected the $\mathrm{pH}$ of the medium as (Fig 4). The initial $\mathrm{pH}$ of all system was 6.97-6.98. During the first $24 \mathrm{~h}$, the $\mathrm{pH}$ of the medium decreased drastically to $4.53,4.65$, and 4.71 in $A_{m}, B_{m}$, and $C_{m}$, respectively. After $30 \mathrm{~h}$, the lowest $\mathrm{pH}$ was in $\mathrm{B}_{\mathrm{m}}\left(\mathrm{pH}\right.$ 3.88). In $\mathrm{A}_{\mathrm{m}}$ the $\mathrm{pH}$ was 4.61. The $\mathrm{pH}$ value stayed the same during $60 \mathrm{~h}$ observation. However, in $\mathrm{C}_{\mathrm{m}}$ after $30 \mathrm{~h}$ the $\mathrm{pH}$ of the medium was 4.35 and slightly decreased to 4.15 after $60 \mathrm{~h}$ observation $\mathrm{pH}$ value reached in fermentation $\mathrm{B}_{\mathrm{m}} \mathrm{pH}$ $3.88 \pm 0.00$ during $60 \mathrm{~h}$ incubation with total glucose added $12 \%$, this $\mathrm{pH}$ was lower than that in Prameela study (Prameela et al. 2010), were $\mathrm{pH} 4.173 \pm 0.01$ was reached using L. plantarum NRRL B-14768 after $72 \mathrm{~h}$ fermentation with $15 \%$ initial glucose added. Jung et al (2005) reported that the $\mathrm{pH}$ value $(\mathrm{pH} 3.52 \pm 0.15)$ of fermentation using L. paracasei KCTC-3074 for $3 \mathrm{~d}$ $(72 \mathrm{~h})$ was slightly lower than our study $(\mathrm{pH}$ $3.88 \pm 0.00$ ). The glucose added in Jung's study was 10\% (Jung et al. 2005).

Bacterial growth, conversion of glucose to lactic acid and change of $\mathrm{pH}$ medium affected ash content of the shrimp shells (Fig 5). For the first $24 \mathrm{~h}$ of fermentation, ash content declined rapidly from initial concentration of $19.26-19.61 \%(\mathrm{w} / \mathrm{v})$ down to 2.9 $3.18 \%(\mathrm{w} / \mathrm{v})$ with reduction rate of the ash concentration in the range of $0.034-0.035 \%(\mathrm{w} / \mathrm{v})$ per hour. The reduction rate of the ash content in the shrimp shells was slowing down afterward until the end of observation $(60 \mathrm{~h})$ in the range of $0.022-0.027 \%(\mathrm{w} / \mathrm{v})$ per hour. The highest ash reduction of the shrimp shells was in $\mathrm{B}_{\mathrm{m}}(99.69 \%)$, followed by $\mathrm{C}_{\mathrm{m}}(97.69 \%)$ and the lowest was in $A_{m}(97.17 \%)$. Therefore, the lowest ash content of the shrimp shells after $60 \mathrm{~h}$ incubation was in fermentation $\mathrm{B}_{\mathrm{m}}(0.06 \pm 0.01 \%$ dry base $)$ followed by $\mathrm{C}_{\mathrm{m}}(0.45 \pm 0.02 \%$ dry base $)$ and $\mathrm{A}_{\mathrm{m}}(0.55 \pm 0.06 \%$ dry base). Based on Duncan Multiple range test, in demineralization process $B_{m}$, there was no significant difference in reduction rate of ash content in the shrimp shells after 24, 36, 42, 48, 54, and $60 \mathrm{~h}$ incubation.
Based on the experimental data, demineralization process of shrimp shells suggested was the fermentation $B_{m}$ with $36 \mathrm{~h}$ incubation, which was subsequent batch with $100 \%$ medium replacement after $24 \mathrm{~h}$. The ash content in $\mathrm{B}_{\mathrm{m}}$ after $36 \mathrm{~h}$ incubation was $0.08 \% \pm 0.00 \%$ (dry base) or $99.61 \% \pm 0.01 \%$ ash removed from the shrimp shells. The results of this demineralization process was better than previous study done by Healy et al (2003), Rao and Stevens (2005), Daum et al. (2007), and Prameela et al. (2012). Healy et al (2003) used a mixture of bacteria ( $L$. plantarum, L. salivarius, Streptococcus faecium, and Pediococcus acidilacti) to demineralize and deproteinize prawn (Nephros norvegicus) at $30{ }^{\circ} \mathrm{C}$ for $7 \mathrm{~d}$, and the final ash removed from the shells was $87.9 \%$. Rao and Stevens (2005), used L. plantarum 541 for demineralization and deproteination, $63 \%$ ash $66 \%$ protein were removed. Daum et al (2007) used shells of Penaeus sp and Lactobacillus sp for demineralization process at $37{ }^{\circ} \mathrm{C}$ for $3 \mathrm{~d}$, with $8 \%$ glucose added, $10 \%$ inoculum $\left(10^{8}\right.$ cells $\left.\mathrm{mL}^{-1}\right)$, resulted in $89.6 \%$ ash removed. Prameela et al (2012) used L. plantarum NRRL B-14768 with $15 \%$ glucose added, the fermentation was done at $37^{\circ} \mathrm{C}$ for $72 \mathrm{~h}$ resulting $76 \%$ ash, and $89 \%$ protein removed.

Deproteination. Deproteination of demineralized shrimp shells was done by cultivating protease producing bacterium $B$. licheniformis F11.1. Three different fermentation systems were applied to optimize protease production for hydrolyzing the protein which associated with the shrimps shells.

In the system $A_{p}$, after $12 \mathrm{~h}$ incubation, the bacterial cells amount declined until the end of observation $(96$ h). In system $B_{p}$ the cells amount decreased from $12 \mathrm{~h}$ to $24 \mathrm{~h}$, then after addition of medium the cell amount increased again until $36 \mathrm{~h}$ incubation, then decreased again until the end of observation $(96 \mathrm{~h})$. In system $\mathrm{C}_{\mathrm{p}}$, after $12 \mathrm{~h}$ incubation, the cell amount decreased until $24 \mathrm{~h}$ of incubation. After addition of inculum after $24 \mathrm{~h}$, the cells amount increased for $12 \mathrm{~h}$ ( $36 \mathrm{~h}$ incubation) then started decreasing until the end of incubation ( 96 h). Among the three fermentation systems, the least cell amount declining rate was in $\mathrm{C}_{\mathrm{p}}$.

The highest protease production in $\mathrm{A}_{\mathrm{p}}(16.06 \pm 0.03$ $\mathrm{U} \mathrm{mL}^{-1}$ ) was reached after $48 \mathrm{~h}$ incubation, in $\mathrm{B}_{\mathrm{p}}$ was after $72 \mathrm{~h}\left(16.51 \pm 0.01 \mathrm{U} \mathrm{mL}^{-1}\right)$ and in $\mathrm{C}_{\mathrm{p}}$ was after $72 \mathrm{~h}$ $\left(11.63 \pm 0.04 \mathrm{U} \mathrm{mL}^{-1}\right)$. Addition of inoculum after $24 \mathrm{~h}$ $\left(\mathrm{B}_{\mathrm{p}}\right)$ only slightly increased the protease production but delayed the maximum production from $48 \mathrm{~h}$ in $\mathrm{A}_{\mathrm{p}}$ to 72 $h$ in $B_{p}$, whilst replacement of medium $\left(C_{p}\right)$ even delayed and decreased the protease production. 
Protease produced by the bacterium would hydrolyze protein in the shrimp shells in the fermentation mixture. During the first $12 \mathrm{~h}$ incubation, the protein content in the shrimp shells was reduced rapidly from $26 \%$ to $13 \%$ ( $\pm 50 \%$ protein removed). At the end of observation in $\mathrm{A}_{\mathrm{p}} ; \mathrm{B}_{\mathrm{p}}$, and $\mathrm{C}_{\mathrm{p}} 94.42 \%, 94.51$ $\%$, and $94.85 \%$ was removed respectively (Fig 8 ). Some studies on microbiological demineralization of shrimp shells were also reported. Daum et al (2003) showed that fermentation using Lactobacillus sp for $48 \mathrm{~h}$ could reduce $95 \%$ protein of shrimp (Penaeus sp) shells. Prameela et al (2010) reported that demineralization of Penaeus monodon shells for $72 \mathrm{~h}$ using L. plantaraum NRRL B-14768 removed $76 \%$ ash, while Rao and Steven (2005) reported that one step deproteination and demineralization of shrimp shells using $L$. plantarum 541 could removed $83 \%$ protein and $88 \%$ ash.

Therefore, considering the operational cost, the fermentation design $\mathrm{B}_{\mathrm{m}}$ (subsequent batch fermentation) in which $100 \%$ medium was replaced with fresh medium after $24 \mathrm{~h}$ fermentation, followed by deproteination system $A_{p}$ (batch fermentation) was suggested. $A_{p}$ system was the easiest and cheapest compared to the other ones. System $A_{p}$ needed neither addition of inoculum nor medium.

\section{REFERENCES}

AOAC. 1984. Official Methods of Analysis. $15^{\text {th }}$ edition. Association of Official Analytical Chemistry, Inc. Virginia: Arlington.

Beany P, Lizardi-Mendoza J, Healy M. 2005. Comparison of chitins produced by chemical and bioprocessing methods. J Chem Technol Biotechnol. 80(2):145-150. doi:10.1002/jctb.1164.

Daum G, Stöber H, Veltrup K, Meinhardt F, Bisping B. 2007. Biotechnological process for chitin recovery out of shrimp waste. J Biotechnol. 131(1):S188. doi:10.1016/j. jbiotec.2007.07.334.

Dutta PK, Dutta J, Tripathi VS. 2004. Chitin and chitosan: properties and applications. J Sci Industrial Res. 63:2031.

Healy M, Geen A, and Healy A. 2003. Bioprocessing of marine crustacean shell waste. Acta Biotechnol. 23 (23):151-260. doi: 10.1002/abio.200390023.

Hoffman K, Daum G, Köster M, Kulicke WM, MeyerRammes H, Bisping B, Meinhardt F. 2010. Genetic improvement of Bacillus licheniformis strains for efficient deproteinization of shrimp shells and production of high-molecular-mass chitin and chitosan.
Appl Environ Microbiol. 76(24):8211-8221.

Hsu YL, Wu WT. 2002. A novel approach for scaling up a fermentation system. Biochem Eng J. 11(2-3):123-130. doi:10.1016/S1369-703X(02)00016-5.

Jafarei P, Ebrahimi MT. 2011. Lactobacillus acidophilus cell structure and application. African J Microbiol Res. 5:4033-4042.

Jung WJ, Jo GH, Kuk JH, Kim KY. Park RD. 2005. Extraction of chitin from red crab shell waste by cofermentation with Lactobacillus paracasei sbsp tolerans KCTC-3074 and Serratia marcescens FS-3. Appl Microbiol Biotechnol.71(2):234-237. doi 10.1007/s00253-005-0126-3.

Junianto, Mangunwidjaja D, Suprihatin, Mulyorini, Wahyuntari B. 2009. Pengaruh tingkat aerasi dan kecepatan agitasi terhadap tingkat hidrolisis protein kulit udang pada tahapan ekstraksi kitin secara biologis [Effect of aeration and agitation rate on protein hydrolysis of shrimp shells in biological chitin extraction]. J Bionatura. 11(2):107-117.

Lowry OH, Rosenbrough NJ, Farr AL, Randall RJ. 1951. Protein measured with folin phenol reagent. J Biochem. 193:265-275.

Mizani A, Aminlari BM. 2007. A New process deproteination of chitin from shrimp head waste. Proceedings of European Congress of Chemical Engineering; 2007 September 16-20. Copenhagen (DK). p 1-8.

Mahmoud NS, Ghay AE, Arab F. 2007. Unconventional approach for demineralization of deproteinized crustacean shells for chitin production. Am J Biochem Biotech.3(1):1-9. doi:10.3844/ajbbsp.2007.1.9.

Prameela K, Mohan CM, Hemalatha KPJ. 2010. Extraction of pharmaceutically important chitin and carotenoid from shrimp biowaste by microbial fermentation method. J Pharmacy Res. 3:2393-2395.

Rao MS, Munoz J, Stevens WF. 2000. Critical factors in chitin production by fermentation of shrimp biowaste. Appl Microbiol Biotechnol. 54(6):808-813. doi:10.100 7/s002530000449.

Rao MS, Stevens WF. 2005. Chitin production by Lactobacillus fermentation of shrimp biowaste in a drum bioreactor and its chemical conversion to chitosan. J Chem Technol Biotechnol. 80(9):10801087. doi:10.1002/jctb.1286.

Wahyuntari B, Junianto, Setyahadi S. 2011. Process design of microbiological chitin extraction. Microbiol Indones. 6(1):36-45. doi:10.5454/mi.5.1.7.

Waldeck J, Daum G, Bisping B, Meinhardt F. 2006. Isolation and molecular characterization of chitinase-deficient Bacillus licheniformis strains capable of deproteiniation of shrimp shell waste to obtain highly viscous chitin. Appl Environ Microbiol. 72(12):7879-85. doi:10.1128/ AEM.00938-06. 